\title{
Correction to: Intra-scan inter-tissue variability can help harmonize radiomics features in $\mathrm{CT}$
}

\author{
Hubert Beaumont ${ }^{1}$ (D) Antoine lannessi ${ }^{2} \cdot$ Jean Michel Cucchi ${ }^{3} \cdot$ Anne-Sophie Bertrand $^{4} \cdot$ Olivier Lucidarme $^{5}$ \\ Published online: 24 September 2021 \\ (c) European Society of Radiology 2021
}

\section{Correction to: European Radiology}

https://doi.org/10.1007/s00330-021-08154-8

The original version of this article, published on 06 August 2021, unfortunately contained a mistake. The following correction has therefore been made in the original: The spelling of Anne-Sophie Bertrand's name was incorrect. The corrected author list is given above. The original article has been corrected.

Publisher's note Springer Nature remains neutral with regard to jurisdictional claims in published maps and institutional affiliations.

The original article can be found online at https://doi.org/10.1007/ s00330-021-08154-8.

Hubert Beaumont

Hubert.beaumont@mediantechnologies.com

1 Median Technologies, 06560 Valbonne, France

2 Centre Antoine Lacassagne, 06189 Nice, France

3 Centre D'Imagerie Medical de Monaco, 98000 Monaco, Monaco

4 Centre Hospitalier Princess Grâce, 98000 Monaco, Monaco

5 Hopital La Pitiè Salepétrière, 75000 Paris, France 